\title{
Genetic Factors in the Pathogenesis of Cholangiocarcinoma
}

\author{
Christopher A. Wadsworth ${ }^{a}$ Peter H. Dixon ${ }^{b}$ Jason H. Wong ${ }^{a}$ \\ Michael H. Chapman ${ }^{d}$ Siobhan C. McKayc Amar Sharifa Duncan R. Spalding ${ }^{c}$ \\ Stephen P. Pereirad Howard C. Thomas ${ }^{a}$ Simon D. Taylor-Robinson ${ }^{a}$ \\ John Whittaker ${ }^{\mathrm{e}}$ Catherine Williamson ${ }^{\mathrm{b}}$ Shahid A. Khan ${ }^{\mathrm{a}}$ \\ aDepartment of Hepatology and Gastroenterology, Institute of Reproductive and Developmental Biology, and \\ 'Department of Hepatobiliary Surgery, Imperial College London, dInstitute of Hepatology, University College \\ London Medical School, ' London School of Hygiene and Tropical Medicine, University of London, London, UK
}

\section{Key Words}

Cholangiocarcinoma $\cdot$ Genetics $\cdot \mathrm{ABCB} 11 \cdot \mathrm{ABCB} 4 \cdot \mathrm{ABCC2} \cdot$

ATP8B1 $\cdot$ NR1H4

\begin{abstract}
Background: Cholangiocarcinoma (CC) is increasing in incidence, but its pathogenesis remains poorly understood. Chronic inflammation of the bile duct and cholestasis are major risk factors, but most cases in the West are sporadic. Genetic polymorphisms in biliary transporter proteins have been implicated in benign biliary disease and, in the case of progressive familial cholestasis, have been associated with childhood onset of CC. In the current study, five biologically plausible candidate genes were investigated: $A B C B 11$ (BSEP), ABCB4 (MDR3), ABCC2 (MRP2), ATP8B1 (FIC1) and NR1H4 (FXR). Methods: DNA was collected from 172 Caucasian individuals with confirmed CC. A control cohort of healthy Caucasians was formed. Seventy-three SNPs were selected using the HapMap database to capture genetic variation around the five candidate loci. Genotyping was undertaken with a competitive PCR-based system. Confirmation of Hardy-Weinberg equilibrium and Cochran-Armitage trend testing were performed using PLINK. Haplotype frequencies were com-
\end{abstract}

pared using haplo.stats. Results: All 73 SNPs were in HardyWeinberg equilibrium. Four SNPs in $A B C B 11$ were associated with altered susceptibility to CC, including the V444A polymorphism, but these associations did not retain statistical significance after Bonferroni correction for multiple testing. Haplotype analysis of the genotyped SNPs in ATP8B1 identified significant differences in frequencies between cases and controls (global $p$ value of 0.005 ). Conclusion: Haplotypes in ATP8B1 demonstrated a significant difference between CC and control groups. There was a trend towards significant association of V444A with CC. Given the biological plausibility of polymorphisms in $A B C B 11$ and $A T P 8 B 1$ as risk modifiers for $C C$, further study in a validation cohort is required.

Copyright $\odot 2011$ S. Karger AG, Basel

\section{Introduction}

Cholangiocarcinoma (CC) is a cancer that arises in the epithelial cells of the bile ducts and has features of cholangiocyte differentiation [1]. Max Durand-Fardel, a French physician, was the first author to describe CC. In 1840, he reported a series of four post mortem exami-

\section{KARGER \\ Fax +41613061234 \\ E-Mail karger@karger.ch}

www.karger.com (c) 2011 S. Karger AG, Basel

0257-2753/11/0291-0093\$38.00/0

Accessible online at:

www.karger.com/ddi
Dr. Shahid A. Khan

Department of Hepatology, Imperial College London

10th Floor QEQM Building, St Mary's Campus, Praed Street

London W2 $1 \mathrm{NY}$ (UK)

Tel. +44 207886 6454/6254, E-Mail shahid.khan@imperial.ac.uk 
nations of patients with jaundice who had rapidly succumbed to their disease. In 3 cases, examination revealed tumours of the pancreas obstructing the bile duct. In the final case, he reported 'a soft, whitish, cancerous material, enveloping and completely filling the bile duct but that did not extend beyond the wall of the duct'. He concluded that this represented a primary cancer of the extrahepatic bile duct [2].

Since 1968, there has been a 15 -fold increase in mortality from CC in the UK, with a similar global trend across industrialised countries [3-5]. CC is now the commonest cause of death from primary liver cancer in the UK, causing over 1,000 deaths per year, exceeding even the mortality due to hepatocellular carcinoma [3]. The mortality rate of CC is equal to its incidence and is so high because presentation is usually too late for complete surgical resection, which is the only cure, and because the cancer is resistant to chemotherapy and radiotherapy. The median age at diagnosis of CC is 65 years and it rarely presents before the 5 th decade, except in patients with primary sclerosing cholangitis (PSC) or uncommon genetic or congenital diseases of the biliary tract $[6,7]$. The prognosis of CC is short, with a median survival of 3-6 months in patients receiving palliative care [8]. Overall, median survival in developed countries is less than 2 years $[8,9]$.

\section{Environmental Toxin Evidence}

Epidemiological studies have implicated a variety of toxins and occupational risks with $\mathrm{CC}$, with varying strength of evidence. Thorotrast, an $\alpha$-particle-emitting radiological contrast containing thorium oxide, was used and subsequently proscribed in the middle of the last century. Thorium oxide has a long half-life and is concentrated in the reticuloendothelial system. It has been incontrovertibly linked with CC and a number of other malignancies, with a latency period of 20-35 years [10]. Thorotrast exposure increases the risk of CC to 300 times that of the general population [6]. Epidemiological studies have also implicated tobacco smoking and alcohol use, although conflicting evidence also exists [11-15]. Occupational exposure to the manufacture of rubber, petrochemicals and varnishes is an independent risk factor for CC. These associations have been ascribed to exposure to chemical by-products, including dioxins and nitrosamines [16]. Pro-mutagenic DNA adducts have been identified in CC-adjacent human tissue, indicating exposure to DNA-damaging exogenous toxins [17]. A proposed common pathway of these environmental risks is exposure of the biliary epithelium to oncogenic substances that have been excreted and concentrated in the bile, causing a sequence of genetic mutations thought to initiate and promote neoplasia [17].

\section{Variation with Ethnicity}

Incidence of CC varies with geography and ethnicity, in part independently. The population of northern Thailand has a very high rate of CC that has been clearly associated with endemic liver fluke infestation in that region. Chile also has a very high incidence, while Australia has a very low incidence; however, there is no clear variation in environmental risk factors between the two countries [6]. Studies of the US population have shown wide variation between different ethnic groups, with rates of 1.22/100,000 in Hispanic Americans and 0.17-0.5/ 100,000 in African Americans [18]. The variation in risk between different ethnic groups living in the same environment suggests a potential genetic influence on susceptibility to CC.

\section{Genetic Factors in CC and Benign Biliary Disease}

A number of genetic diseases are risk factors for CC. Lynch syndrome (HNPCC) and biliary papillomatosis, which are both genetic conditions, increase the risk of CC [19]. Biliary papillomatosis carries a huge (85\%) risk of conversion to CC [20]. These inborn genetic mutations appear to offer a biliary epithelial substrate that is highly vulnerable to subsequent oncogenic factors.

Genetic defects leading to congenital abnormalities in bile salt transporter proteins, such as the bile salt exporter pump, (BSEP/ABCB11), familial intrahepatic cholestasis protein 1 (FIC1/ATP8B1) and multidrug resistant protein 3 (MDR3/ABCB4), cause cholestatic disease in infants. These defects result in unstable bile content and deconjugation of xenobiotics, previously conjugated in the liver [5, 21,22]. Very early onset hepatocellular carcinoma and CC have been reported in children with progressive familial intrahepatic cholestasis (PFIC) type 2, caused by BSEP/ABCB11 deficiency [7, 23, 24].

Recent studies have demonstrated a number of polymorphisms in biliary transporter genes, including $A B C B 4$ and $A B C B 11$, which increase the risk of cholelithiasis - a major risk factor for CC [25-28]. A recent study of a cohort of women with intrahepatic cholestasis of pregnancy 
demonstrated an association between a SNP in $A B C B 11$ and the disease [29].

Genetic factors in PSC, the major risk factor for CC in Western populations, have been investigated extensively. Genetic variation in the human leukocyte antigen complex on chromosome 6 p21 has been repeatedly associated with PSC. Studies of specific genes have been small and negative to date, including a study of $A B C B 11$ and $A B C B 4$ $(\mathrm{n}=37)$ [30]. A recent national genome-wide association study in Norway demonstrated associations between polymorphisms in human leukocyte antigen-B, macrophage-stimulating 1, G protein-coupled bile acid receptor 1 and PSC [31]. Large-scale international genomewide association studies into PSC are underway.

A number of studies of candidate genes in CC, each examining between 30 and 216 cases, have reported a positive association with the disease. These studies have generally been performed on populations from the Far East and have focussed on polymorphisms affecting enzymes of xenobiotic metabolism (glutathione S-transferase, GST01, N-acetyltransferase 1, NAT2 and cytochrome P450 1A2, CYP1A2) and folate metabolism (methylenetetrahydrofolate reductase, MTHFR) [32-35]. Several of these studies included gallbladder cancer, and even ampullary tumours, with CC cases. All have yet to be replicated in validation cohorts. A recent study explored the possible association of polymorphisms in G-protein signal transduction and apoptosis. One of the three SNPs studied was associated only with an improved prognosis in extrahepatic CC [36]. Genes modifying natural killer cell activation (natural killer cell receptor G2D, NKG2D) have been implicated in a number of neoplasms and have been investigated in PSC patients with CC. Two of the seven SNPs studied were associated with altered susceptibility to CC in PSC [37]. Polymorphisms in NKG2D have yet to be investigated in sporadic CC.

A recent study in a small cohort $(n=60)$ of patients found a polymorphism in the multidrug resistance-associated protein 2 (MRP2) gene $A B C C 2$ was associated with $\mathrm{CC}$ [38]. MRP2 is an ATP-binding cassette (ABC) biliary transporter expressed on the apical membrane of hepatocytes and cholangiocytes. The c.3972 C>T SNP genotype was significantly more frequent in CC (39.2\%) versus controls $(26.0 \%, \mathrm{p}=0.022)$ with an OR of 1.83 (95\% CI: 1.09-3.08). MRP2 is a reasonable candidate susceptibility protein as it plays a critical role in the excretion of xenobiotics and polymorphisms in $A B C C 2$ have been associated with hepatocellular carcinoma. This is the only published study of biliary transporter proteins as risk factors for CC.

Genetic Factors in the Pathogenesis of Cholangiocarcinoma

\section{Canalicular Transporter Proteins}

The hepatobiliary system is the major route of metabolism and excretion for genotoxic, potentially carcinogenic, endogenous and environmental toxins. Exposure to environmental toxins has increased in the past few decades and some of these toxins have been implicated in the pathogenesis of CC [39-41]. However, given that only a small percentage of Western populations develop CC, it follows that genetic differences in the host response to these pathological stimuli may play a role in cholangiocarcinogenesis.

Biliary excretion of bile salts, conjugated toxins and other components is performed by transporters expressed on the apical surface of hepatocytes and cholangiocytes [42]. These biliary transporters also govern the rate of bile flow, and dysfunction of the transporters is a leading cause of cholestasis [43]. Bile flow and constituents vary between individuals. The biliary proteins involved in the physiological production of bile have only been relatively recently described, and their functions in health and disease remain only partially understood.

A reduction in the flow of bile (cholestasis) and abnormal biliary constituents may result in increased exposure of cholangiocytes lining the biliary epithelium to xenobiotics and endogenous mutagens, such as hydrophobic bile acids. These bile acids have a strong detergent action that disrupts cell membranes. The formation of bile acids, phosphatidylcholine (PtC) and cholesterol into stable micelles in the bile serves to protect the biliary system from such damage [42]. Disequilibrium of biliary components is known to lead to biliary deconjugation of toxic species previously conjugated in the liver.

BSEP (ABCB11) is a member of the superfamily of $A B C$ transporters. $A B C$ proteins transport various molecules across extra- and intracellular membranes. ABC genes are divided into seven subfamilies (ABC1, MDR/ TAP, MRP, ALD, OABP, GCN20, White). BSEP is responsible for the active transport of bile acids across the hepatocyte canalicular membrane into bile, and secretion of bile acids is a major determinant of bile flow [22, 43]. Underexpression of BSEP is implicated in PFIC type 2.

MDR3 (ABCB4) is a phosphatidylcholine floppase that translocates $\mathrm{PtC}$ from the inner to the outer leaflet of the canalicular membrane. PtC is critical in the formation of stable micelles in bile. Polymorphisms in ABCB4 may lead to a reduction in MDR3 protein function and biliary PtC levels, resulting in unstable micelle formation. MDR3 deficiency has been implicated in PFIC type 3.

Dig Dis 2011;29:93-97 
Table 1. Summary of the names, encoding genes, known functions and associated diseases of the proteins

\begin{tabular}{|c|c|c|c|c|c|c|}
\hline $\begin{array}{l}\text { Protein } \\
\text { abbr. }\end{array}$ & Trivial name & Full name & $\begin{array}{l}\text { Gene } \\
\text { abbr. }\end{array}$ & Known function & Distribution in liver & $\begin{array}{l}\text { Associated } \\
\text { diseases }\end{array}$ \\
\hline BSEP & $\begin{array}{l}\text { bile salt exporter } \\
\text { pump }\end{array}$ & $\begin{array}{l}\text { ATP-binding cassette, sub-family B } \\
\text { (MDR/TAP), member } 11\end{array}$ & $A B C B 11$ & bile acid transport & $\begin{array}{l}\text { hepatocyte apical } \\
\text { membrane }\end{array}$ & $\begin{array}{l}\text { PFIC-2, HCC, } \\
\text { BRIC-2 }\end{array}$ \\
\hline MDR3 & $\begin{array}{l}\text { multidrug resistance } \\
\text { protein } 3\end{array}$ & $\begin{array}{l}\text { ATP-binding cassette, sub-family B } \\
\text { (MDR/TAP), member } 4\end{array}$ & $A B C B 4$ & PtC transport & $\begin{array}{l}\text { hepatocyte apical } \\
\text { membrane }\end{array}$ & $\begin{array}{l}\text { PFIC-3, } \\
\text { gallstone disease }\end{array}$ \\
\hline FIC1 & $\begin{array}{l}\text { familial intrahepatic } \\
\text { cholestasis protein } 1\end{array}$ & $\begin{array}{l}\text { ATPase, aminophospholipid } \\
\text { transporter, class I, type } 8 \mathrm{~B} \text {, } \\
\text { member } 1\end{array}$ & ATP8B1 & $\begin{array}{l}\text { translocation of acidic } \\
\text { phospholipids in cell } \\
\text { membrane }\end{array}$ & $\begin{array}{l}\text { hepatocyte and } \\
\text { cholangiocyte apical } \\
\text { membranes }\end{array}$ & $\begin{array}{l}\text { PFIC-1/Byler's } \\
\text { disease, BRIC-1 }\end{array}$ \\
\hline FXR & $\begin{array}{l}\text { farnesoid X receptor/ } \\
\text { bile acid receptor }\end{array}$ & $\begin{array}{l}\text { nuclear receptor subfamily } 1 \text {, } \\
\text { group } \mathrm{H} \text {, member } 4\end{array}$ & $\mathrm{NR} 1 \mathrm{H} 4$ & $\begin{array}{l}\text { transcriptional regulation of } \\
\mathrm{ABCB} 4 \text { and } A B C B 11\end{array}$ & $\begin{array}{l}\text { hepatocytes and } \\
\text { cholangiocytes }\end{array}$ & $\begin{array}{l}\text { cholestasis, } \\
\text { gallstone disease }\end{array}$ \\
\hline
\end{tabular}

MRP2 (ABCC2) is a member of the MRP subfamily and has a known role in drug elimination and resistance. It is expressed in the canalicular apical membrane of the hepatocyte and exports numerous conjugated species into the bile. Substrates include conjugated bilirubin and other anionic-conjugated species, including many drugs and toxins.

FIC1 (ATP8B1) is a member of the P-type cation transport ATPase family and belongs to the subfamily of aminophospholipid-transporting ATPases. It is highly expressed in cholangiocytes and the canalicular membranes of hepatocytes, and is also found in the small intestine, stomach, pancreas and prostate. FIC1 transports phosphatidylserine and phosphatidylethanolamine from the outer membrane leaflet to the inner, maintaining the correct distribution of these lipids in the membrane and thereby membrane integrity. FIC1 dysfunction is associated with the disease PFIC type 1.

FXR (NR1H4) is a nuclear receptor and is expressed at high levels in the liver and intestine. Chenodeoxycholic acid and other bile acids are natural ligands for FXR. When activated, FXR translocates to the cell nucleus and binds to hormone response elements on DNA which up- or downregulate the expression of specific genes. FXR activation suppresses the production of cholesterol $7 \alpha$-hydroxylase (CYP7A1), the rate-limiting enzyme in bile acid synthesis from cholesterol. This forms a negative feedback pathway in which synthesis of bile acids is inhibited when cellular levels are already high. FXR also modifies the expression of other genes, including ABCB11 and $\mathrm{ABCB} 4$ (table 1).
It is highly likely that host and environmental factors interact in the development of CC. The range of proteins involved in bile formation has only been described relatively recently and the full extent of their functions and interactions has likely not been fully elucidated. However, variation in these proteins is known to modify the rate of bile formation, its flow, stability and toxicity. Genetic variation in host bile formation, physiology and flow may thereby modify susceptibility to CC.

\section{Disclosure Statement}

The authors have no conflicts of interest to declare.

References

Wadsworth et al.
1 de Groen PC, Gores GJ, LaRusso NF, Gunderson LL, Nagorney DM: Biliary tract cancers. N Engl J Med 1999;341:1368-1378.

2 Durand-Fardel M: Recherches anat-path. Sur la vesicule et les canaux biliaires. Arch gen de Med 1840;viii:167.

3 Taylor-Robinson SD, Toledano MB, Arora S, Keegan TJ, Hargreaves S, Beck A, Khan SA, Elliott P, Thomas HC: Increase in mortality rates from intrahepatic cholangiocarcinoma in England and Wales 1968-1998. Gut 2001; 48:816-820.

4 Khan SA, Davidson BR, Goldin R, Pereira SP, Rosenberg WM, Taylor-Robinson SD, Thillainayagam AV, Thomas HC, Thursz MR, Wasan H: Guidelines for the diagnosis and treatment of cholangiocarcinoma: consensus document. Gut 2002;51(suppl 6):VI1VI9. 
$\checkmark 5$ Khan SA, Thomas HC, Davidson BR, TaylorRobinson SD: Cholangiocarcinoma. Lancet 2005;366:1303-1314.

6 Shaib Y, El-Serag HB: The epidemiology of cholangiocarcinoma. Semin Liver Dis 2004; 24:115-125.

7 Scheimann AO, Strautnieks SS, Knisely AS, Byrne JA, Thompson RJ, Finegold MJ: Mutations in bile salt export pump (ABCB11) in two children with progressive familial intrahepatic cholestasis and cholangiocarcinoma. J Pediatr 2007;150:556-559.

8 Shaib YH, Davila JA, Henderson L, McGlynn KA, El-Serag HB: Endoscopic and surgical therapy for intrahepatic cholangiocarcinoma in the United States: a population-based study. J Clin Gastroenterol 2007; 41:911-917.

-9 Ortner MA: Photodynamic therapy for cholangiocarcinoma: overview and new developments. Curr Opin Gastroenterol 2009;25: 472-476.

-10 Sahani D, Prasad SR, Tannabe KK, Hahn PF, Mueller PR, Saini S: Thorotrast-induced cholangiocarcinoma: case report. Abdom Imaging 2003;28:72-74.

-11 Welzel TM, Graubard BI, El-Serag HB, Shaib YH, Hsing AW, Davila JA, McGlynn KA: Risk factors for intrahepatic and extrahepatic cholangiocarcinoma in the United States: a population-based case-control study. Clin Gastroenterol Hepatol 2007;5:1221-1228.

-12 Welzel TM, Mellemkjaer L, Gloria G, Sakoda LC, Hsing AW, El Ghormli L, Olsen JH, McGlynn KA: Risk factors for intrahepatic cholangiocarcinoma in a low-risk population: a nationwide case-control study. Int J Cancer 2007;120:638-641.

13 Shaib YH, El-Serag HB, Nooka AK, Thomas M, Brown TD, Patt YZ, Hassan MM: Risk factors for intrahepatic and extrahepatic cholangiocarcinoma: a hospital-based casecontrol study. Am J Gastroenterol 2007;102: 1016-1021.

- 14 Tao LY, He XD, Qu Q, Cai L, Liu W, Zhou L, Zhang SM: Risk factors for intrahepatic and extrahepatic cholangiocarcinoma: a casecontrol study in China. Liver Int 2010;30 215-221.

15 Grainge MJ, West J, Solaymani-Dodaran M, Aithal GP, Card TR: The antecedents of biliary cancer: a primary care case-control study in the United Kingdom. Br J Cancer 2009; 100:178-180.

- 16 Hardell L, Bengtsson NO, Jonsson U, Eriksson S, Larsson LG: Aetiological aspects on primary liver cancer with special regard to alcohol, organic solvents and acute intermittent porphyria - an epidemiological investigation. Br J Cancer 1984;50:389-397.

$\checkmark 17$ Khan SA, Carmichael PL, Taylor-Robinson SD, Habib N, Thomas HC: DNA adducts, detected by $32 \mathrm{P}$ postlabelling, in human cholangiocarcinoma. Gut 2003;52:586-591.

18 McLean L, Patel T: Racial and ethnic variations in the epidemiology of intrahepatic cholangiocarcinoma in the United States. Liver Int 2006;26:1047-1053.

19 Mecklin JP, Jarvinen HJ, Virolainen M: The association between cholangiocarcinoma and hereditary nonpolyposis colorectal carcinoma. Cancer 1992;69:1112-1114.

20 Lee SS, Kim MH, Lee SK, Jang SJ, Song MH, Kim KP, Kim HJ, Seo DW, Song DE, Yu E, Lee SG, Min YI: Clinicopathologic review of 58 patients with biliary papillomatosis. Cancer 2004;100:783-793.

21 Jacquemin E: Role of multidrug resistance 3 deficiency in pediatric and adult liver disease: one gene for three diseases. Semin Liver Dis 2001;21:551-562.

22 Thompson R, Strautnieks S: BSEP: function and role in progressive familial intrahepatic cholestasis. Semin Liver Dis 2001;21:545-550.

-23 Knisely AS, Strautnieks SS, Meier Y, Stieger B, Byrne JA, Portmann BC, Bull LN, Pawlikowska L, Bilezikci B, Ozcay F, Laszlo A, Tiszlavicz L, Moore L, Raftos J, Arnell H, Fischler B, Nemeth A, Papadogiannakis N, Cielecka-Kuszyk J, Jankowska I, Pawlowska J, Melin-Aldana H, Emerick KM, Whitington PF, Mieli-Vergani G, Thompson RJ: Hepatocellular carcinoma in ten children under five years of age with bile salt export pump deficiency. Hepatology 2006;44:478-486.

24 Meier Y: Hepatocellular malignancy in ABCB11/BStP disease (progressive familial intrahepatic cholestasis, type 2): four patients. Hepatology 2004;40S:471 A.

25 Rosmorduc O, Hermelin B, Boelle PY, Parc R, Taboury J, Poupon R: ABCB4 gene mutation-associated cholelithiasis in adults. Gastroenterology 2003;125:452-459.

26 Lucena JF, Herrero JI, Quiroga J, Sangro B Garcia-Foncillas J, Zabalegui N, Sola J, Herraiz $\mathrm{M}$, Medina JF, Prieto J: A multidrug resistance 3 gene mutation causing cholelithiasis, cholestasis of pregnancy, and adulthood biliary cirrhosis. Gastroenterology 2003; 124:1037-1042.

27 Lammert F, Wang DQ, Hillebrandt S, Geier A, Fickert P, Trauner M, Matern S, Paigen B, Carey MC: Spontaneous cholecysto- and hepatolithiasis in $\mathrm{Mdr2} 2^{-/}$mice: a model for low phospholipid-associated cholelithiasis. Hepatology 2004;39:117-128.

28 van Mil SW, van der Woerd WL, van der Brugge G, Sturm E, Jansen PL, Bull LN, van den Berg IE, Berger R, Houwen RH, Klomp LW: Benign recurrent intrahepatic cholestasis type 2 is caused by mutations in ABCB11. Gastroenterology 2004;127:379-384.

29 Dixon PH, van Mil SW, Chambers J, Strautnieks S, Thompson RJ, Lammert F, Kubitz R, Keitel V, Glantz A, Mattsson LA, Marschall HU, Molokhia M, Moore GE, Linton KJ, Williamson C: Contribution of variant alleles of $\mathrm{ABCB} 11$ to susceptibility to intrahepatic cholestasis of pregnancy. Gut 2009;58:537-544.

- 30 Pauli-Magnus C, Kerb R, Fattinger K, Lang T, Anwald B, Kullak-Ublick GA, Beuers U, Meier PJ: BSEP and MDR3 haplotype structure in healthy Caucasians, primary biliary cirrhosis and primary sclerosing cholangitis. Hepatology 2004;39:779-791.

31 Karlsen TH, Franke A, Melum E, Kaser A, Hov JR, Balschun T, Lie BA, Bergquist A, Schramm C, Weismuller TJ, Gotthardt D, Rust C, Philipp EE, Fritz T, Henckaerts L, Weersma RK, Stokkers P, Ponsioen CY, Wij- menga C, Sterneck M, Nothnagel M, Hampe J, Teufel A, Runz H, Rosenstiel P, Stiehl A, Vermeire S, Beuers U, Manns MP, Schrumpf E, Boberg KM, Schreiber S: Genome-wide association analysis in primary sclerosing cholangitis. Gastroenterology 2010;138:11021111.

32 Marahatta SB, Punyarit P, Bhudisawasdi V, Paupairoj A, Wongkham S, Petmitr S: Polymorphism of glutathione S-transferase omega gene and risk of cancer. Cancer Lett 2006; 236:276-281.

33 Wiencke K, Louka AS, Spurkland A, Vatn M, Schrumpf E, Boberg KM: Association of matrix metalloproteinase-1 and -3 promoter polymorphisms with clinical subsets of Norwegian primary sclerosing cholangitis patients. J Hepatol 2004;41:209-214.

34 Ko KH, Kim NK, Yim DJ, Hong SP, Park PW, Rim KS, Kim S, Hwang SG: Polymorphisms of 5,10-methylenetetrahydrofolate reductase (MTHFR C677T) and thymidylate synthase enhancer region (TSER) as a risk factor of cholangiocarcinoma in a Korean population. Anticancer Res 2006;26:4229-4233.

- 35 Prawan A, Kukongviriyapan V, Tassaneeyakul W, Pairojkul C, Bhudhisawasdi V: Association between genetic polymorphisms of CYP1A2, arylamine $\mathrm{N}$-acetyltransferase 1 and 2 and susceptibility to cholangiocarcinoma. Eur J Cancer Prev 2005;14:245-250.

- 36 Fingas CD, Katsounas A, Kahraman A, Siffert W, Jochum C, Gerken G, Nuckel H, Canbay A: Prognostic assessment of three single-nucleotide polymorphisms (GNB3 $825 \mathrm{C}>\mathrm{T}$, BCL2-938C $>$ A, MCL1-386C $>\mathrm{G})$ in extrahepatic cholangiocarcinoma. Cancer Invest 2010;28:472-478.

- 37 Melum E, Karlsen TH, Schrumpf E, Bergquist A, Thorsby E, Boberg KM, Lie BA: Cholangiocarcinoma in primary sclerosing cholangitis is associated with NKG2D polymorphisms. Hepatology 2008;47:90-96.

38 Hoblinger A, Grunhage F, Sauerbruch T, Lammert F: Association of the c.3972C >T variant of the multidrug resistance-associated protein 2 Gene (MRP2/ABCC2) with susceptibility to bile duct cancer. Digestion 2009;80:36-39.

39 Dougherty CP, Holtz SH, Reinert JC, Panyacosit L, Axelrad DA, Woodruff TJ: Dietary exposures to food contaminants across the United States. Environ Res 2000;84:170-185.

40 Kjeller LO, Jones KC, Johnston AE, Rappe C: Increases in the polychlorinated dibenzo-Pdioxin and dibenzo-P-furan content of soils and vegetation since the 1840s. Environ Sci Technol 1991;25:1619-1627.

41 Alcock RE, Johnston AE, Mcgrath SP, Berrow ML, Jones KC: Long-term changes in the polychlorinated biphenyl content of United Kingdom soils. Environ Sci Technol 1993;27: 1918-1923.

42 Trauner M, Boyer JL: Bile salt transporters: molecular characterization, function, and regulation. Physiol Rev 2003;83:633-671.

43 Pauli-Magnus C, Stieger B, Meier Y, KullakUblick GA, Meier PJ: Enterohepatic transport of bile salts and genetics of cholestasis. J Hepatol 2005;43:342-357. 